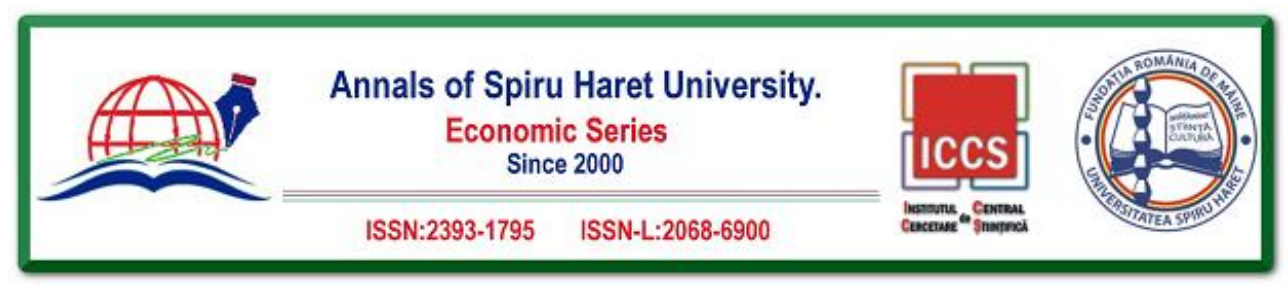

Issue 4/2018

\title{
CORRUPTION AND STOCK MARKET PERFORMANCE
} IN NIGERIA

\author{
Cordelia Onyinyechi OMODERO ${ }^{1}$, Kabiru I. DANDAGO ${ }^{2}$ \\ ${ }^{1}$ Department of Accounting, College of Management Sciences, Micheal \\ Okpara University of Agriculture, Umudike, Abia State, Nigeria, E-mail: \\ cordeliaomodero@yahoo.com. \\ ${ }^{2}$ Prof. Ph.D., FCA, FCTI, FNIM, MNES, AAIF, Department \\ of Accounting, Faculty of Social \& Management Sciences, Bayero \\ University, Kano, Nigeria, Telephone: +2348023360386, \\ E-mail: kidandago@gmail.com
}

How to cite: OMODERO, O. C. \& DANDAGO, K. I. (2018). "Corruption and Stock Market Performance in Nigeria.” Annals of Spiru Haret University. Economic Series, 18(4), 23-40, doi: https://doi.org/10.26458/1842

\section{Abstract}

The study examines the effect of corruption (using corruption perception index and Nigeria corruption ranking as proxies) on the stock market performance (proxied with share price index) in Nigeria. The study employed time series data spanning twenty years (1996-2016). Data availability especially on corruption indices was the major reason underlying the choice of period. The data were obtained from CBN Statistical Bulletin and Transparency International website. With the aid of SPSS version 20, the study used Multi-regression analysis and student t-test for the test of hypotheses. The study finds a significant positive correlation between corruption and stock market performance in Nigeria. The result reveals robust positive and significant relationships between Nigeria Corruption Ranking, Corruption perception index and Share price index. The result of the study explains the integration of graft into the Nigerian economic system. Therefore, adoption of a strong form of stock market efficiency by the Security and Exchange Commission (SEC) and Nigerian Stock Exchange (NSE) for actualization by all listed firms in Nigeria is hereby recommended. In addition, we recommend that the Federal and State governments should formulate more result-oriented policies and rules that could help combat corruption more effectively. 


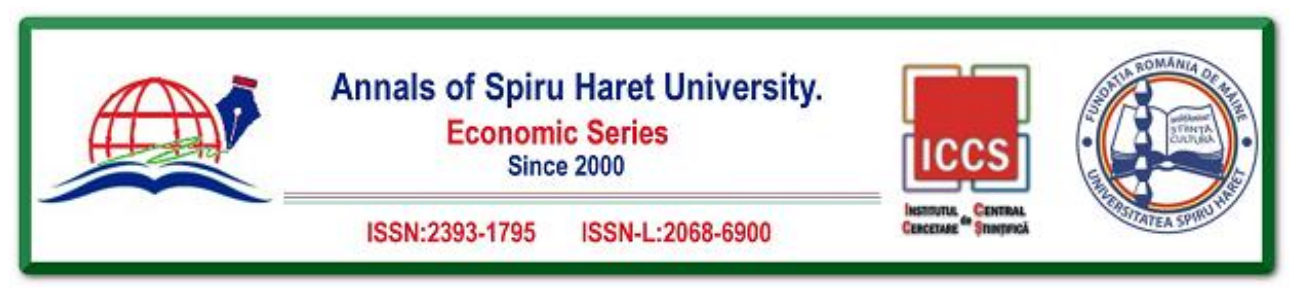

Issue 4/2018

Keywords: stock market performance; corruption; share price index; corruption perception index; Nigeria Corruption Ranking.

JEL Classification: G15

\section{Introduction}

Corruption is a cankerworm that gradually and silently depletes the fabrics of a nation's economy as well as reducing development in all sectors (EFCC, 2005). Transparency International (2005) stated that corruption is one of the fundamental challenges of the present times in the world which destabilizes good government, ultimately misrepresents good policies, causes misuse of public resources, destroys the private sector development and also hurts the poor masses. According to Mustapha (2008), corruption has eaten so deep into the fabrics of the Nigerian government, the public and private sectors, governmental and non-governmental organizations and has basically turned out to be a life style and a key means of amassing private property in Nigeria. ICPC (2006) has stated that corruption is the major cause of the underdevelopment in Nigeria. Transparency International reports from 1996 until today have shown Nigeria as one of the highest ranking countries on corruption index perception. Ribadu (2003) posits that the level of corruption in Nigeria has made the Transparency International to consistently rate Nigeria as one of the top three most corrupt countries in the world. The existence of corruption in almost every sector of the Nigerian economy has adversely affected both foreign and local investments in Nigeria. As part of the government's effort to combat this menace, the Nigerian government tried to establish anti-graft agencies such as Economic and Financial Crime Commission (EFCC) and the Independent Corrupt Practices and related offences Commission (ICPC). The major aim is to encourage private investors and make the Nigerian business environment conducive for investors [African Economic Outlook, 2011]. As part of the successes made so far in the corruption fight, the Federal Ministry of Information released the recovered billions from corrupt persons in May 29, 2015 (N78,325,354,631.82; \$185,119,584.61; £3,508,355.46) and (Euro 11,250) in May 25, 2016 [Adesanya, 2016]. The truth of the matter is that stock market in Nigeria is not exempted in this struggle. Stock market is a market that deals with the exchange of securities issued by publicly quoted companies and the government owned corporations [Ashaolu \& Ogunmuyiwa, 2010]. It affords businesses, government and individual investors with an opportunity to raise capital through selling of shares to the 


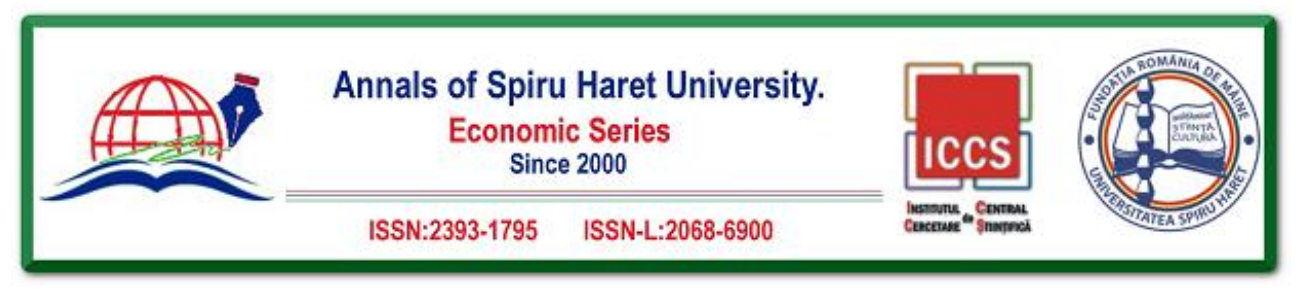

Issue 4/2018

investors [Black and Gilson, 1998]. The market is a vital institution in an economy which critically defines and highlights the performance of an economy [Ashaolu \& Ogunmuyiwa, 2010]. Therefore, as an essential pillar of a country's economy, government bodies, corporations, stockholders (both the existing and potential ones) and all stakeholders judiciously study and monitor the activities of the stock market [Nazir, Nawaz, \& Gilani, 2010]. However, the investment decision of these stakeholders depends on their observation and perception of the stock market performance. Corruption led to the loss of Stock Market integrity in Nigeria as it was witnessed in the late 1990s and early 2000, when so many banks collapsed under their watch [Babalola, 2010]. During this period, the number of banks classified as distressed increased from 8 to 52 [CBN, 1997]. Prior to the introduction of N25 billion recapitalization policy for banks in Nigeria in 2004 by the then CBN governor, the CBN announced the revocation of the banking licenses of 26 banks due to their financial distress [Babalola, 2010]. Investors' confidence in financial reporting of companies were lost due to the issue of window dressing that kept increasing share prices of companies that even had financial and corporate governance challenges. Though, the introduction of corporate governance structure was supposed to serve as a deterrent to all manner of cosmetic accounting in companies, yet frequent board room squabbles, insider abuses, fraud and forgeries, weak/ineffective internal control system would not give room for the objective to be achieved [Babalola, 2010]. Therefore, it is pertinent to note that the effect of graft on stock market performance in Nigeria is even more grievous than the influence of the external factors such as inflation, exchange rate and interest rate. This is because graft is inherent and exists at all levels of system. The major objective of this paper is to investigate the effect of corruption on the stock market performance in Nigeria and to suggest remedial measures to our policy makers. The specific objective of the study is to examine the impact of corruption (using corruption perception index and country ranking as proxies) on the stock market performance (to be represented by All Share Index in Nigeria).

\section{Research hypotheses}

The following null hypotheses have been formulated to test the effect of corruption on stock market performance.

$\mathrm{HO}_{1}$ : Corruption Perception Index of Nigeria does not have any significant impact on the Share Price Index in Nigeria.

$\mathrm{HO}_{2}$ : Nigerian Corruption Ranking does not significantly influence Share Price Index in Nigeria. 


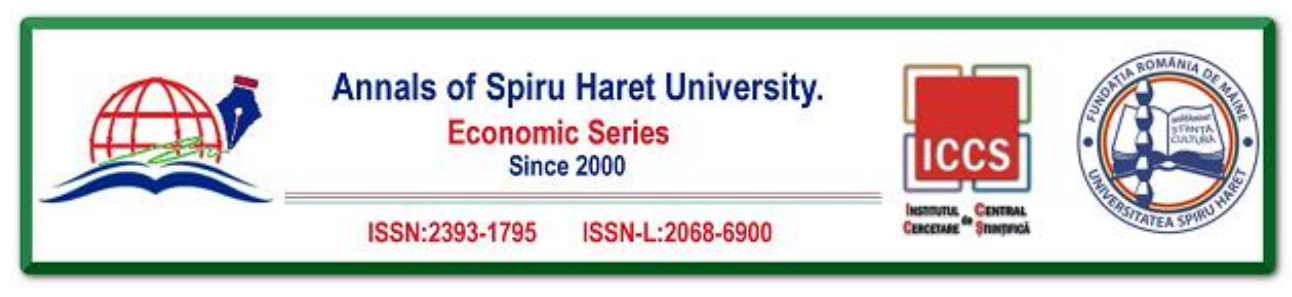

\section{Issue 4/2018}

\section{Literature Review}

\section{Conceptual Framework and Definitions}

The focus of this study is to examine the effect of corruption on the stock market performance in Nigeria. Therefore, the dependent variable used as proxy for stock market performance is the Share Price Index, while the independent variables are the Corruption Perception Index and the Nigeria Corruption Ranking among other countries in the world.

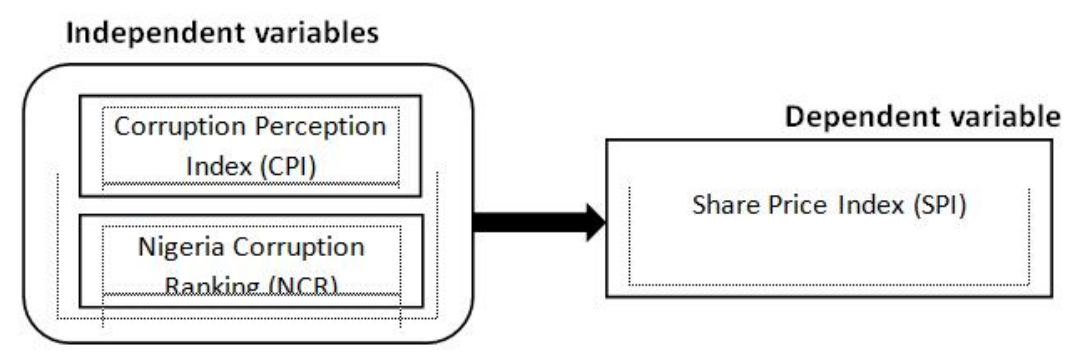

Fig. 1. Conceptual Framework on the Effect of Corruption on the Stock Market Performance

Source: Desk Research (2018)

\section{Corruption}

Corruption is the misuse of delegated authority for personal benefits [Transparency International, 2011]. It is also a deliberate way of misrepresenting facts, realities and management of situation in which someone finds himself in an effort to deceive and gain both material and non-material things [Akinlabi, Hamed, \& Awoniyi, 2011]. According to Hasan \& Nuri (2013), corruption is the misuse of public office for private gains. It is globally held that corruption is endemic and pervasive in nature, thereby constituting a major hindrance to economic and investment growth, also impacts negatively the public service delivery as well as increases the social inequality [Bolgorian, 2011]. Natalia (2016) posits that corruption includes bribery, extortion, and misuse of insider information and thrives where policy enforcement is lacking. Looking at different definitions of corruption and in the context of this study, corruption could be defined as any form of manipulation of corporate information and accounting data in which investors rely upon to believe in share prices and make investment decisions. 


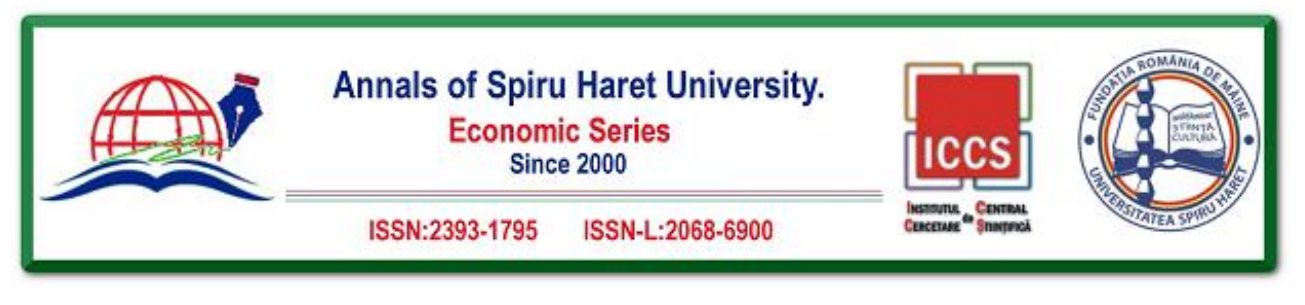

Issue 4/2018

\section{Corruption Perception Index}

Corruption is a variable that is complex to measure statistically. Therefore, Transparency International in collaboration with some organizations provided corruption indices that could help assess the level of corruption around the world. These organizations include European Bank for Reconstruction and Development (EBRD), World Bank Business Environment and Enterprise Performance Survey, Freedom House's Nations in Transit etc. [Natalia, 2016]. Transparency International (TI) Corruption perception index (CPI) is a collective pointer that positions nations in relation to the level of corruption that is observed to occur among public officials and politicians. It is a compound index portraying all corruption-related data from a variety of reputable institutions based on surveys of domestic and international business executives, financial journalists, and risk analysts who are experts and business elites. Data captured for CPI usage does not include views of the general public [Transparency International, 2011]. CPI scale measurement is between 0-100. The score scale of 0 means that the level of corruption in that country is very high while 100 is used to depict a country that is very clean. TI is an International Nongovernmental Organization established in 1993 with the aim of bringing together business, civil society, and government structures to fight graft. The CPI first publication by TI was in 1995 and it covered quite a number of countries [Natalia, 2016].

\section{Nigeria Corruption Ranking}

This is the ranking position of Nigeria in terms of corruption when compared to other countries in the world.

From the table below it is worthy to note that Nigeria ranked $1^{\text {st }}$ as the most corrupt country in 1996, 1997 and 2000. From 2014 to 2016, the position has remained at 136 despite all efforts of the government to minimize graft in the system.

\section{Stock market}

Stock market refers to an equity market and is one of the important areas of a market economy as it gives firms access to capital while both the existing and potential investor could also be part of a company's ownership through acquisition of shares [Osoro, 2013]. Stock Market development plays a crucial role for the global economy and finance [Hasan \& Nuri, 2013]. The Nigerian Stock Exchange (NSE) is 


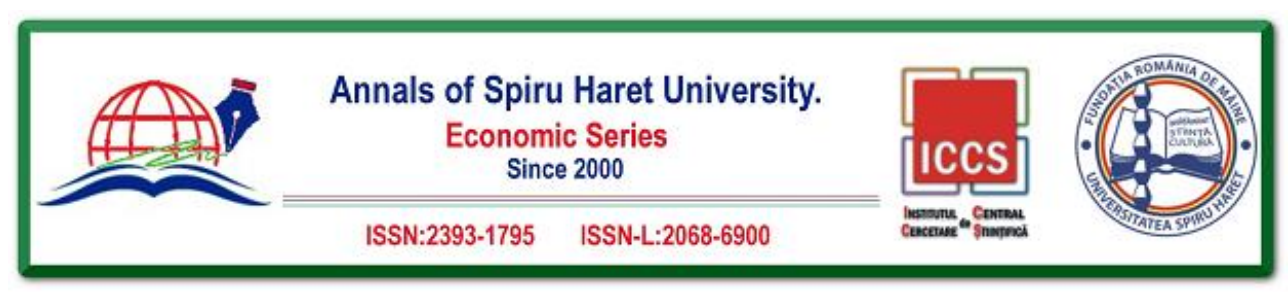

\section{Issue 4/2018}

a primary market that allows firms and other organizations to source for capital through issue of shares or loan stocks. It is also referred to as a secondary market where existing securities (shares and loan stocks) are being traded [Akinsulire, 2006]. NSE was established in 1960 as the Lagos Stock Exchange. The name was changed from the Lagos Stock Exchange to the Nigerian Stock Exchange (NSE) in 1977. About 176 firms were listed on the NSE as at March 7, 2017 and in terms of market capitalization, NSE stands as the third largest Stock Exchange in Africa with the total market capitalization of about N8.5 trillion [NSE, 2017].

Table 1. Transparency International corruption perception index ranking of Nigeria corruption from 1996 to 2016

\begin{tabular}{|c|c|c|}
\hline$Y E A R$ & $\begin{array}{c}\text { NIGERIA CORRUPTION } \\
\text { RANKING }\end{array}$ & $\begin{array}{c}\text { NUMBER OF COUNTRIES } \\
\text { CAPTURED BY TI }\end{array}$ \\
\hline 1996 & 54 & 54 \\
\hline 1997 & 52 & 52 \\
\hline 1998 & 81 & 85 \\
\hline 1999 & 98 & 99 \\
\hline 2000 & 90 & 90 \\
\hline 2001 & 90 & 91 \\
\hline 2002 & 101 & 102 \\
\hline 2003 & 132 & 133 \\
\hline 2004 & 144 & 145 \\
\hline 2005 & 152 & 158 \\
\hline 2006 & 142 & 163 \\
\hline 2007 & 147 & 179 \\
\hline 2008 & 121 & 180 \\
\hline 2009 & 130 & 180 \\
\hline 2010 & 134 & 183 \\
\hline 2011 & 143 & 182 \\
\hline 2012 & 139 & 174 \\
\hline 2013 & 144 & 175 \\
\hline 2014 & 136 & 174 \\
\hline 2015 & 136 & 167 \\
\hline 2016 & 136 & 176 \\
\hline
\end{tabular}

Source: Transparency International 


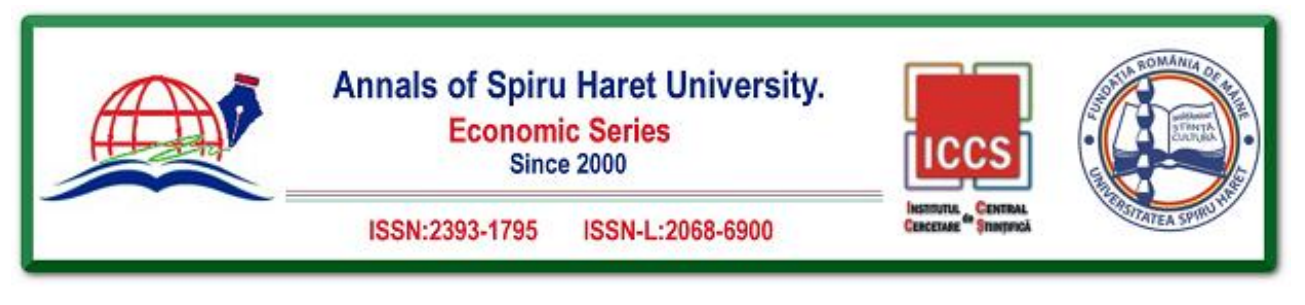

Issue 4/2018

\section{Share price index}

Share price is used as a yardstick to measure a firm's performance and its deviations as pointer of the economic health or otherwise of a firm hence the need to be conversant with the factors that could adversely affect share prices [Osoro, 2013]. Share price index is a way of measuring the performance of a market and is used by investors and capital providers to compare their return with that of the market [Barasa, 2014].

\section{Stock market performance}

Stock market performance is the appraisal of an efficient market. A basic feature of an efficient capital market is constant liquidity, an easy mechanism for entry and exit by investors. This requires sufficient volume and size of transactions in the market [Yartey and Adjasi, 2007].

\section{Theoretical Review}

The study has been anchored on the theories below.

\section{A Policy-Oriented Theory of Corruption}

Teveik, Albert and Charles (1986) propounded this theory in their effort to elaborate the responsibilities of the government in anti-graft fight. The theory stated that the existence of corruption in both developed or developing countries will always result in a dwindling economy. Therefore, the government's endeavour to develop policies and strategies to combat corruption and to seriously investigate its effect on all facets of the economy remains a huge benefit.

\section{Market Efficiency Theory}

Barasa (2014) described efficient market as one that is rational and provides correct pricing. Fama (2000) carried out a detailed empirical work and review on efficient market theory and came up with the definition that market efficiency is one in which prices always reflect all available information. Fama (2000) identified three sets of information which include: past prices, publicly available information and all other information which includes private information. The information available to investors could make them change their mind and investment decision on a particular security and the value. According to Akinsulire (2006), this is what is referred to as an efficient market hypothesis. The efficient market hypothesis is divided into three forms: the weak form, semi-strong form, and the strong form. The weak form of efficiency reflects all historical market data such as past prices 


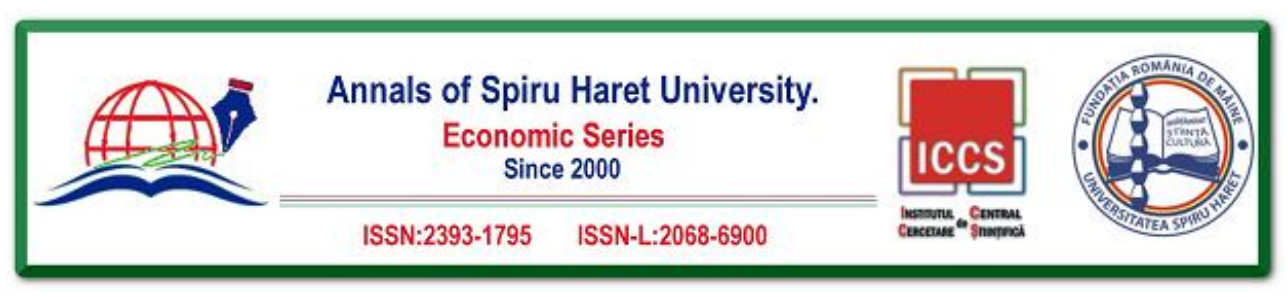

\section{Issue 4/2018}

and trading volumes without any prediction of future prices [Fama, 2000]. Semi strong form of efficiency reveals current share prices in addition to the past prices, all publicly available information which includes basic data regarding the firm's product line, quality of management, published accounting information, divided and even stock split announcements [Akinsulire, 2006]. The strong form of efficiency reflects share price and all past prices, publicly available information and private information [Fama, 2000].

\section{Empirical studies}

Nageri, Umar and Abdul (2013) examined the impact of corruption and economic development in Nigeria. Time series data spanning from 1996 to 2012 were obtained from the World Bank and Transparency International. The study used GDP as the dependent variable while the independent variables were the Corruption Perception Index (CPI), Corruption Rank and the Relative Corruption Rank. Ordinary least squares (OLS) technique was used for the analysis. The result revealed that corruption had a significant negative effect on economic growth and development in Nigeria. The study suggested that corrupt government officials and politicians should be brought to justice if found guilty at any point in time.

Hasan and Nuri (2013) investigated the role of corruption and banking sector development on Stock Market development using a panel data of 42 emerging economies for the period 1996 to 2011. The result revealed among others that corruption had a more devastating effect on these countries' stock market development than the positive effects of the banking sector development. In a similar study, O'Toole and Tarp (2014) tested the effect of corruption on the efficiency of capital investment using firm-level data from World Bank Enterprise Surveys which covered 90 developing and transition economies. The study's primary objective was to evaluate the extent to which bribery was reducing marginal returns on capital investments. The findings revealed that bribery decreased investment efficiency such that the negative impact was most robust on small and medium sized enterprises.

Sunkanmi and Isola (2014) studied the relationship between corruption and economic growth in Nigeria. The study made use of Ordinary Least Squares (OLS) technique and time series data spanning from 1980 to 2010 which were gathered from CBN Statistical Bulletin, Anti-graft agencies reports and other secondary sources. The dependent variables were the Foreign Direct Investment, Gross Domestic Product, government expenditure in Nigeria and globalization openness of the economy while the level of perceived corruption was the independent variable used. The study found evidence that corruption had a positive significant 


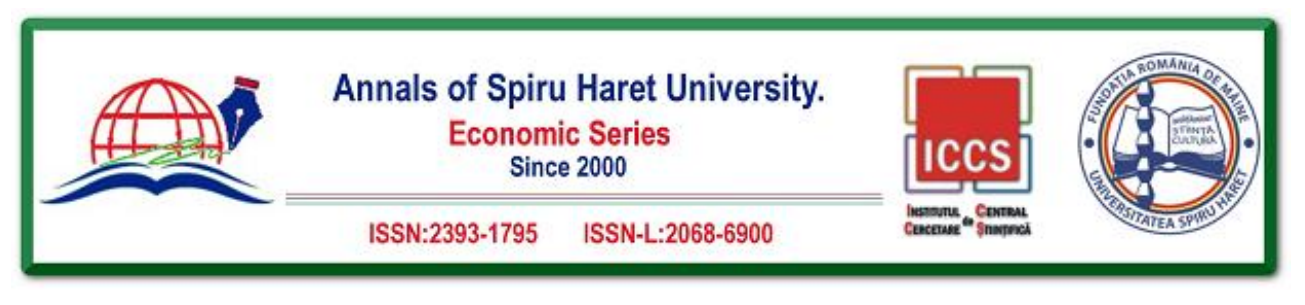

Issue 4/2018

relationship with the Foreign Direct Investment (FDI), Gross Capital Formation (GCF) and government expenditure but found no significant relationship between corruption and GDP as well as openness of the economy and globalization. The result indicated that the level of corruption in the country had become an important element for economic growth. The study did not find this suitable and suggested that the anti-graft agencies in Nigeria should be more empowered to fight graft while more awareness should be created among young people on the importance of moral values.

Nwankwo (2014) employed granger causality and regression techniques to investigate the impact of corruption on the growth of Nigerian economy. The study made use of GDP as proxy for economic growth while corruption index was used as the independent variable. The result indicated a negative influence of corruption on the economic growth. The study recommended the formulation of policies that could minimize corruption and poverty hindering the growth of the Nigerian economy.

Barasa (2014) investigated the effect of selected macro-economic determinants on stock market performance in Kenya. The selected macro-economic variables were inflation rate, money supply, real GDP per capita while NSE-20 share index was used as proxy for stock market performance. The study employed descriptive research design and made use of secondary data which covered the period from 2000 to 2013. The data on NSE 20-share were obtained from Nairobi Securities Exchange, the data on consumer price index were collected from Central Bank of Kenya. The real GDP per capita data were gotten from the Kenya National Bureau of Statistics while the money supply data were gathered from the International Monetary Fund website. The data analysis was done with the aid of SPSS version 20. The result of the study revealed that CPI had an insignificant negative impact on share price index, money supply and real GDP did not have impact on share price index at all. The study suggested that the policy makers should influence macro-economic variables in the right direction, stressing that there should be enough money supply to move the stock market forward.

Kpanie, Esumanba and Sare (2014) examined the relationship between stock market performance and macroeconomic variables in Ghana. The study made use of Error Correction Model and the Augmented Dickey-Fuller Co-integration for analysis. The macroeconomic variables used for the test were money supply, Treasury bill, inflation rate, exchange rate and oil prices while the dependent variable was the Ghana All Share Index. The secondary data employed spanned from 1995 to 2011 and were obtained from the Ghana Stock Exchange and Bank of Ghana. The result of the study showed that oil prices and money supply were statistically 


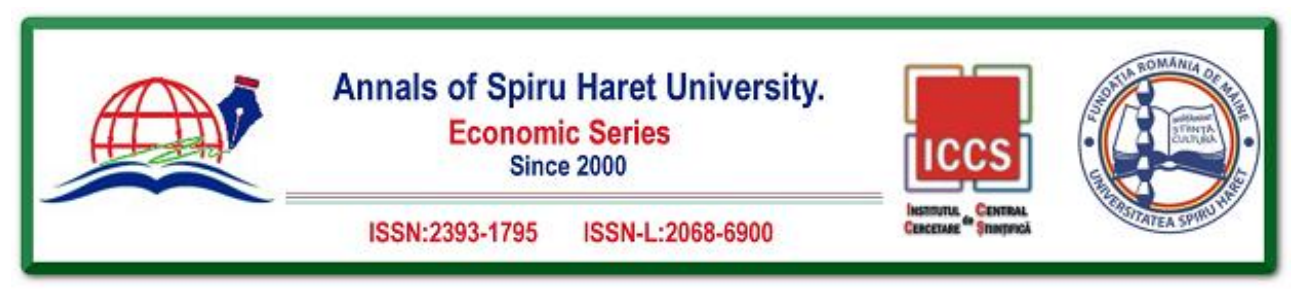

\section{Issue 4/2018}

significant at $1 \%$ level in explaining the influence of macroeconomic variables on the Ghana Stock Exchange. The rest of the variables showed an evidence of a long run relationship. The study suggested a more careful implementation of macroeconomic policies that will boost the performance of the stock market in Ghana.

Worlu and Omodero (2017) investigated the impact of macroeconomic variables on stock market performance in Africa using Nigeria, Ghana, Kenya and South Africa as case studies. The research design adopted was a cross sectional survey. Time series data covering the period of 2000 to 2015 were utilized and collected from the Central Banks and National Bureau of Statistics of the countries used for the study. The dependent variable used as proxy for stock market performance was the share price index while the control variables explaining the degree of impact of macroeconomic variables on stock market performance were the GDP, Inflation rate and Real Effective Exchange Rate Index. Statistical Package for Social Sciences version 20 was employed for the multi-regression analysis. The study found a very weak relationship between the explanatory variables and the share price index on almost all the countries studied. The result revealed that inflation rate had a negative impact on stock market performance in Nigeria and South Africa. It was also revealed that Exchange Rate had negative effect on stock market performance in Nigeria and Kenya. Stock market in Nigeria was adversely affected by all the macroeconomic variables used for the study. The study suggested that policy makers in the African countries should endeavour to make policies that could control these variables to avoid the negative influence on stock markets.

\section{Critique of Literature}

The studies on the impact of macroeconomic variables on stock market performance both in Nigeria and other countries showed divergent results. Barasa (2014) study in Kenya had both negative and insignificant influence on share prices. Kpanie, Esumanba and Sare's (2014) study in Ghana revealed significant relationship between share prices and macroeconomic variables. The study of Worlu and Omodero (2017) on four African countries showed evidence that macro-economic variables had negative impact on the share price index of the four African countries used as case studies. Looking at the corruption impact on the economy, Nwankwo (2014) supported the study of Nageri, Umar and Abdul (2013) but disagreed with the study of Sunkanmi and Isola (2014) which stated that corruption is relevant for economic growth even though it is a bad omen and evil at all levels. The effect of corruption on stock market efficiency evidenced by few studies was significantly negative [Hasan \& Nuri, 2013; O’Toole \& Tarp, 2014]. 


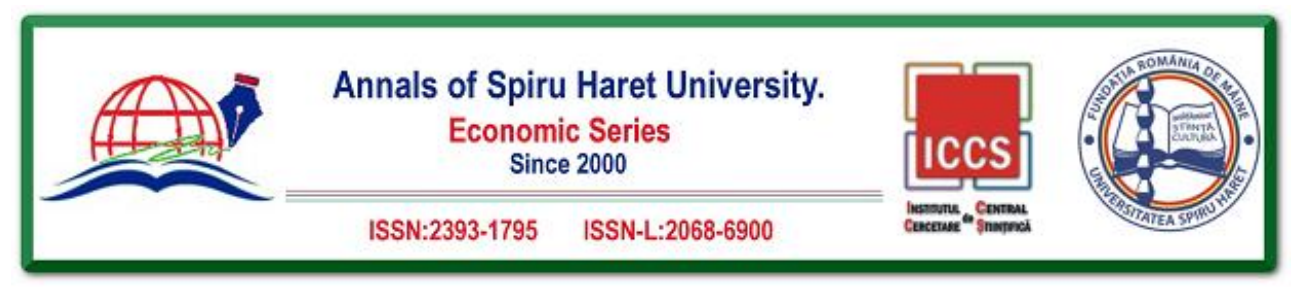

Issue $4 / 2018$

\section{Research Gap}

The studies reviewed so far concentrated on the impact of corruption on economic growth using foreign direct investment inflows and different economic indicators while those on the stock market performance made use of macroeconomic variables such as inflation, exchange rate, money supply and GDP. Studies that evaluated the effect of corruption on stock market performance are yet very scarce. Stock market is a very vital institution in a nation's economy and it is therefore pertinent to monitor all issues and factors that influence it both positively and negatively of which corruption is one of the issues. This is the gap this current study intends to fill. The study has been planned to investigate the effect of corruption on the stock market performance in Nigeria.

\section{Methodology}

Descriptive research design has been adopted for this study. Descriptive research design gives accurate information of situations as they naturally occur [Groove, 2004]. This research design has been employed because it allows numerical collection of data for research variables which can be statistically analyzed to produce empirical evidences of a chosen research field. The statistical tool for the analysis is the multi-regression technique and student t-test for testing the hypotheses. The dependent variable selected for the study is the Nigerian All Share Price Index (SPI) and the independent variables are the Corruption Perception Index (CPI) and the Nigerian Corruption Ranking (NCR) among other countries in the world. The SPI data were collected from the CBN Statistical Bulletin (2016) while the CPI and NCR were obtained from the Transparency International website. All hypotheses were tested at $5 \%$ level of significance for acceptance (if higher) or rejection (if lower).

\section{Model specification}

The model for the study is specified as:

$\begin{array}{lll}\text { SPI } & = & \mathrm{f}(\mathrm{CPI}, \mathrm{NCR}) \\ \text { Where } & & \\ \text { SPI } & = & \text { Share Price Index. } \\ \text { CPI } & = & \text { Corruption Perception Index. } \\ \text { NCR } & = & \text { Nigeria Corruption Ranking. }\end{array}$




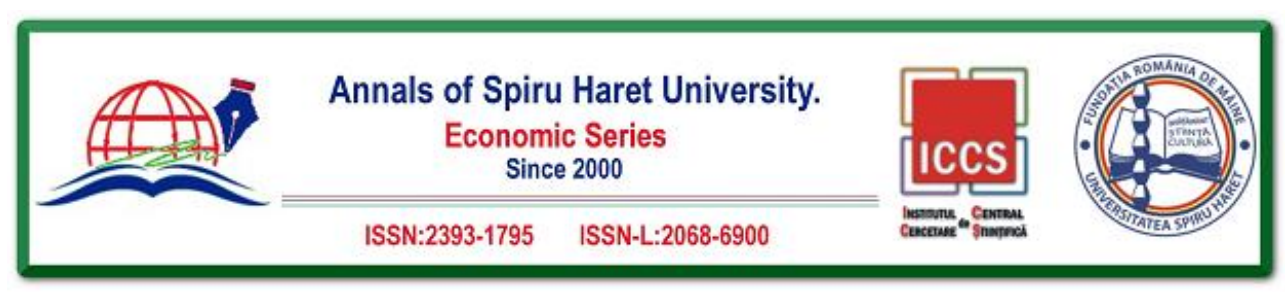

\section{Issue 4/2018}

The stochastic form is stated as:
$\mathrm{Y} \quad=$
$\mathrm{b} 0+\mathrm{bX} 1+\mathrm{b} 2 \mathrm{X} 2+\mu$
Where $\mu=$
random error term.

\section{Results and Interpretations}

Table 2. Model Summary Statistics

\section{Model Summary}

\begin{tabular}{|c|c|c|c|c|c|}
\hline Model & $\mathrm{R}$ & $\mathrm{R}$ Square & $\begin{array}{c}\text { Adjusted R } \\
\text { Square }\end{array}$ & $\begin{array}{c}\text { Std. Error of the } \\
\text { Estimate }\end{array}$ & Durbin-Watson \\
\hline 1 & $0.846^{\mathrm{a}}$ & 0.715 & 0.684 & 0.175953866 & 1.076 \\
\hline
\end{tabular}

a. Predictors: (Constant), NCR, CPI

Source: Research Findings 2018.

In the table 2 above $\mathrm{R}$ is 0.846 (84.6\%) and $\mathrm{R}^{2}$ is 0.715 (71.5\%). This implies that there is a significant relationship between the dependent variable (Share Price Index) and the independent variables (Corruption Perception Index and Nigerian Corruption Ranking). The correlation (R) is very high, likewise the $\mathrm{R}^{2}$ which is the coefficient of determination showing the extent to which the independent variables explain the changes in the dependent variable.

Table 3. Analysis of Variance

\begin{tabular}{|c|c|c|c|c|c|c|}
\hline \multicolumn{2}{|c|}{ ANOVA } \\
\hline \multicolumn{2}{|c|}{ Model } & $\begin{array}{c}\text { Sum of } \\
\text { Squares }\end{array}$ & Df & Mean Square & F & Sig. \\
\hline \multirow{3}{*}{1} & Regression & 1.401 & 2 & 0.701 & 22.626 & $0.000^{b}$ \\
\cline { 2 - 7 } & Residual & 0.557 & 18 & 0.031 & & \\
\cline { 2 - 7 } & Total & 1.958 & 20 & & & \\
\hline \multicolumn{2}{|l}{ b. Predictors: (Constant), NCR, CPI }
\end{tabular}

Source: Research Findings 2018 


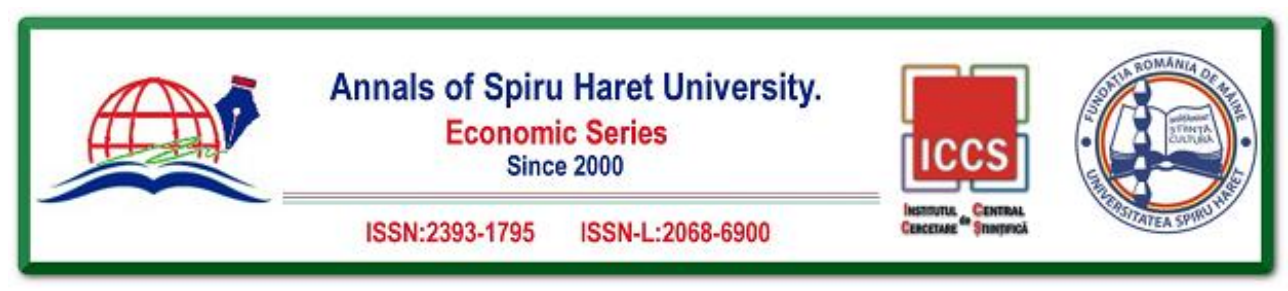

Issue 4/2018

Table 3 shows that the regression model is a good fit and it is statistically significant $(0.000<0.5)$.

Table 4. Model Coefficients

\begin{tabular}{|c|c|c|c|c|c|c|}
\hline \multicolumn{7}{|c|}{ Coefficients } \\
\hline & \multirow[t]{2}{*}{ Model } & \multicolumn{2}{|c|}{ Unstandardized Coefficients } & \multirow{2}{*}{$\begin{array}{c}\begin{array}{c}\text { Standardized } \\
\text { Coefficients }\end{array} \\
\text { Beta }\end{array}$} & \multirow[t]{2}{*}{$t$} & \multirow[t]{2}{*}{ Sig. } \\
\hline & & $B$ & Std. Error & & & \\
\hline \multirow[t]{3}{*}{1} & (Constant) & 0.012 & 0.633 & & 0.019 & 0.985 \\
\hline & $C P I$ & 0.692 & 0.328 & 0.354 & 2.110 & 0.049 \\
\hline & NCR & 1.295 & 0.383 & 0.568 & 3.383 & 0.003 \\
\hline
\end{tabular}

Table 4 shows that the model equation can be presented as follows:

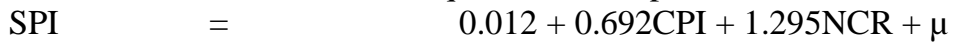

Source: Research Findings 2018

\section{Test of hypotheses}

The study earlier hypothesized that corruption does not have significant impact on the stock market performance in Nigeria. From the table 4 above, CPI has a positive significant impact on SPI (i.e. $0.049<0.05$ ) and the NCR equally has a positive and robust significant impact on SPI (i.e. $0.003<0.05$ ). Therefore the hypotheses earlier formulated are rejected.

\section{Discussion on the findings}

The findings of this current study does not agree with the empirical studies of Hasan \& Nuri (2013); Nageri, Umar \& Abdul (2013); Nwankwo (2014); O’Toole \& Tarp (2014), but seem to be consistent with the study of Sunkanmi and Isola (2014) who found a positive significant relationship between corruption and macro-economic variables such as FDI, GCP and government expenditure. It is pertinent to point out that corruption is inherent in the Nigerian system and because it has become a way of life, almost every sector of the economy is growing with it. The stock market is where companies trade their shares to raise capital. The existence of corruption in the Nigerian stock market spells danger and may mean betrayal of trust in the Nigerian business environment. No wonder companies still collapse even when their share prices are on the rising side. Macroeconomic variables seem to have adverse effect on the stock market performance and yet the 


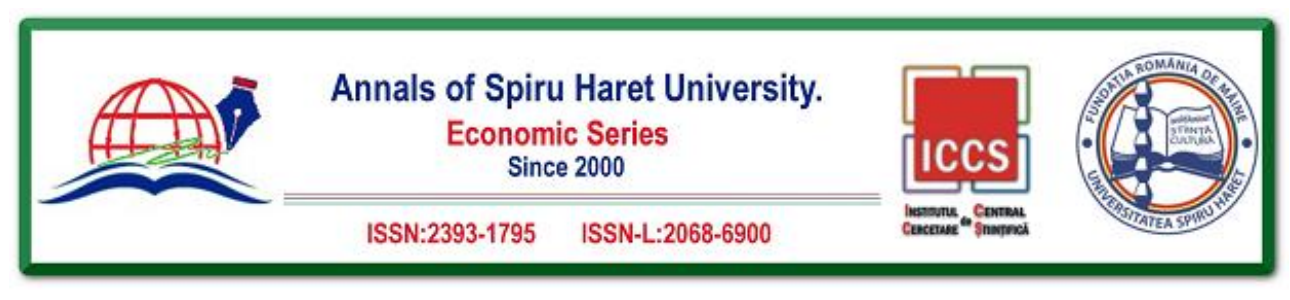

\section{Issue 4/2018}

effect of corruption is positive and significant. This could be an area for further research.

\section{Conclusion and Recommendation}

The issue of corruption in Nigeria should bother everyone. It is a fight that must be taken seriously. It has been so integrated into the Nigerian system that all efforts to eliminate it seem to prove abortive. This study suggests that Companies should ensure there is a proper corporate governance structure in their organizations which is made up of people that believe in transparency and public accountability. The integrity of external auditors should be investigated before they are allowed to carry out any professional assignment in an organization. The anti-graft agencies should be strengthened and encouraged to do their work effectively. The government should flush out all corrupt public office holders and adopt a policy oriented theory of corruption by Teveik, Albert \& Charles (1986). The Stock Market in Nigeria requires a lot of measures to ensure that all private information about companies reflect in their share prices to save investors economic loss. The authorities should lay more emphasis on the practice of strong form of market efficiency which ensures that no stone is left unturned in gathering all information capable of determining share prices of companies wishing to raise capital. 
Annals of Spiru Haret University.

Economic Series

Since 2000

APPENDIX 1: RESEARCH DATA

\begin{tabular}{|c|c|c|c|}
\hline YEAR & SPI & CPI & NCR \\
\hline 1996 & $5,955.14$ & 0.7 & 54 \\
\hline 1997 & $7,638.59$ & 1.8 & 52 \\
\hline 1998 & $5,961.87$ & 1.9 & 81 \\
\hline 1999 & $5,264.19$ & 1.6 & 98 \\
\hline 2000 & $6,701.17$ & 1.2 & 90 \\
\hline 2001 & $10,185.08$ & 1.0 & 90 \\
\hline 2002 & $11,631.87$ & 1.6 & 101 \\
\hline 2003 & $15,559.89$ & 1.4 & 132 \\
\hline 2004 & $24,738.65$ & 1.6 & 144 \\
\hline 2005 & $22,876.72$ & 1.9 & 152 \\
\hline 2006 & $25,343.55$ & 2.2 & 142 \\
\hline 2007 & $48,773.31$ & 2.2 & 147 \\
\hline 2008 & $50,424.71$ & 2.7 & 121 \\
\hline 2009 & $23,091.55$ & 2.5 & 130 \\
\hline 2010 & $24,775.52$ & 2.4 & 134 \\
\hline 2011 & $23,393.65$ & 2.4 & 143 \\
\hline 2012 & $23,432.62$ & 2.7 & 139 \\
\hline 2013 & $36,207.08$ & 2.5 & 144 \\
\hline 2014 & $39,409.83$ & 2.7 & 136 \\
\hline 2015 & $30,867.20$ & 2.6 & 136 \\
\hline 2016 & $26,624.08$ & 2.8 & 136 \\
\hline
\end{tabular}

Source: CBN Statistical Bulletin and Transparency International. 
Annals of Spiru Haret University.

Economic Series

Since 2000

ISSN:2393-1795 ISSN-L:2068-6900

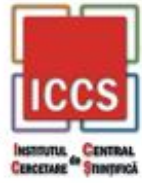

\section{Issue 4/2018}

APPENDIX 2: LOG OF RESEARCH DATA

\begin{tabular}{|c|c|c|c|}
\hline$Y E A R$ & SPI & $C P I$ & $N C R$ \\
\hline & $L O G$ & $L O G$ & $L O G$ \\
\hline 1996 & 3.774892 & 1.845098 & 1.732394 \\
\hline 1997 & 3.883013 & 2.255272 & 1.716003 \\
\hline 1998 & 3.775383 & 2.278754 & 1.908485 \\
\hline 1999 & 3.721332 & 2.204120 & 1.991226 \\
\hline 2000 & 3.826151 & 2.079181 & 1.954243 \\
\hline 2001 & 4.007964 & 2.000000 & 1.954243 \\
\hline 2002 & 4.065650 & 2.204120 & 2.004321 \\
\hline 2003 & 4.192007 & 2.146128 & 2.120574 \\
\hline 2004 & 4.393376 & 2.204120 & 2.158362 \\
\hline 2005 & 4.359394 & 2.278754 & 2.181844 \\
\hline 2006 & 4.403867 & 2.342423 & 2.152288 \\
\hline 2007 & 4.688182 & 2.342423 & 2.167317 \\
\hline 2008 & 4.702643 & 2.431364 & 2.082785 \\
\hline 2009 & 4.363453 & 2.397940 & 2.113943 \\
\hline 2010 & 4.394023 & 2.380211 & 2.127105 \\
\hline 2011 & 4.369098 & 2.380211 & 2.155336 \\
\hline 2012 & 4.369821 & 2.431364 & 2.143015 \\
\hline 2013 & 4.558794 & 2.397940 & 2.158362 \\
\hline 2014 & 4.595605 & 2.431364 & 2.133539 \\
\hline 2015 & 4.489497 & 2.414973 & 2.133539 \\
\hline 2016 & 4.425275 & 2.447158 & 2.133539 \\
\hline
\end{tabular}

Source: CBN Statistical Bulletin and Transparency International. 


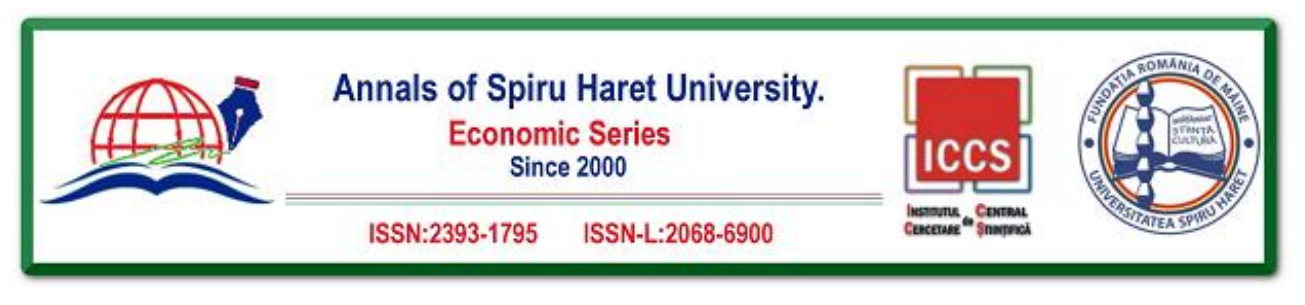

Issue 4/2018

\section{References}

1. Adesanya, F. (2016). "Federal Government Releases List of Recovered Loot Information Nigeria”. African Economic Outlook (2006). Nigeria. African Economic Outlook 2005-2006. Retrieved from www.oecd.org/africanoutlook on January 18, 2018.

2. Akinlabi, A. O., Hamed, B., \& Awoniyi, M. A. (2011). "Corruption, Foreign Direct Investment and Economic Growth in Nigeria: An Empirical Investigation”. Journal of Research in International Business Management, 1(9), 278-292.

3. Akinsulire, O. Financial Management. Fourth Edition. Lagos: Ceemol Nigeria Limited, 2006.

4. Ashaolu, T. O., \& Ogunmuyiwa, M. S. (2011). "An Econometric Analysis of the Impact of Macroeconomic Variables on Stock Market Movement in Nigeria". Journal of Business Management, 3(1), 72-78.

5. Babalola, A. (2010). "Corporate Governance in Banks: The Nigerian Experience". Corporate Ownership and Control International Journal, Ukraine, Special Conference Issue, 7(4), 34-41.

6. Barasa, J. W. Macro-Economic Determinants of Stock Market Performance in Kenya: Case of Nairobi Securities Exchange. Msc. Degree Research Project submitted to the School of Business University of Nairobi, 2014.

7. Black, B. S., \& Gilson, R. J. (1998). "Venture Capital and the Structure of Capital Markets: Banks versus Stock Markets.” Journal of Financial Economics, 47(3), 243277, https//dx.doi.org/10.1016/50304-405X (97)00045-7.

8. Bolgorian, M. (2012). "Corruption and Stock Market Development. A Quantitative Approach.” Physica A (390), 4514-4521.

9. Central Bank of Nigeria. CBN Briefs Series Nos 97/01-97/12, Research Department, 1997.

10. EFCC. Effect of corruption on Nigeria's economy. Nigeria EFCC Information Communication Technology Department. Abuja, 2005.

11. Fama, E. F. Short-Term Interest Rates as predictors of inflation. The Debt Market. Cheltenham: Elgar, 2000.

12. Groves, R. E. Survey Methodology. Sage publications: California, 2004.

13. ICPC. Nigeria and Corruption. Independent Corrupt Practices and other related offences Commission, 2006.

14. Hasan, A., \& Nuri, B. (2013). “Corruption, Banking Sector, and Stock Market Development: A Panel Data Analysis. International Association of Social Science Research - IASSR.” European Journal of Research on Education, 2013, Special Issue: Human Resource Management, 94-99.

15. Kpanie, A. F., Esumanba, S. V., \& Sare, Y. A. (2014). "Relationship between Stock Market Performance and Macroeconomic Variables in Ghana." Issue in Business Management and Economics, 2(3), 046-053. 


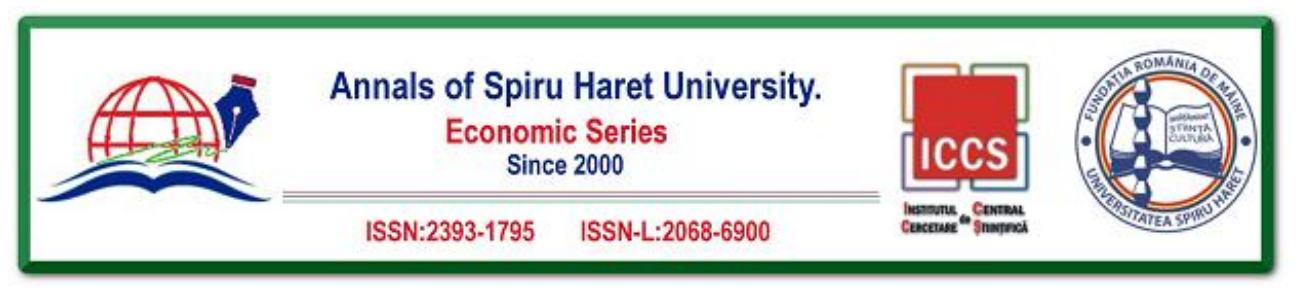

\section{Issue 4/2018}

16. Mustapha, M. A. (2008). "Combating Corruption in Nigeria: The Role of the Legislature Examined.” The University of Ilorin Law Journal, 3\&4, 57-79.

17. Natalia (2016). Corruption Perception Index. https://www.britannica.com/. Retrieved: February 18, 2018.

18. Nazir, M. S., Nawaz, M. M., \& Gilani, U. J. (2010). "Relationship between Economic Growth and Stock Market Development.” African Journal of Business Management, 4(6), 3473-3479.

19. Nigerian Stock Exchange (2017). The Nigerian Stock Market. Retrieved: February 18, 2018.

20. Nwankwo, O. (2014). "Impact of Corruption on Economic Growth in Nigeria." Mediterranean Journal of Social Sciences, 5(6), 41-46.

21. Osoro, C. (2013). "Investors' Perspectives on the NASI and the NSE 20 Share Index as Performance Measurement Indicators at the Nairobi Securities Exchange in Kenya." International Journal of Humanities and Social Science, 3(18).

22. O’Toole, C. M., \& Tarp, F. (2014). "Corruption and the Efficiency of Capital Investment in Developing Countries.” Journal of International Development, 26, 567-597.

23. Ribadu, M. N. (2003). "Economic Crime and Corruption in Nigeria: The Causes, Effects, and Efforts Aimed at Combating These Vices in Nigeria.” Paper presented at the Monaco World Summit $5^{\text {th }}$ International Summit on Transnational Crime, Monte Carlo, $23^{\text {rd }}$ and $24^{\text {th }}$ October 2003.

24. Sunkanmi, O. A., \& Isola, A. L. (2014). "Corruption and Economic Growth in Nigeria." Journal of Economics and Sustainable Development, 5(6), 45-56.

25. Tevei, F. N., Albert, C. P., \& Charles, S. (1986). "A Policy Oriented Theory of Corruption.” American Political Science Review, Published in United State of America, University of Michigan, Flint.

26. Transparency International (2011). Corruption Perception Index. https://www.transparency.org.

27. Worlu, C. N., \& Omodero, C. O. (2017). "A Comparative Analysis of Macroeconomic Variables and Stock Market Performances in Africa (2000-2015).” International Journal of Academic Research in Accounting, Finance and Management Sciences, 7(4), 95-102.

28. Yartey, C. A., \& Adejasi, C. K. (2007). "Stock Market Development in Sub-Saharan African: Critical Issues and Challenges.” IMF Working paper No. 07/209.IMF. 